\title{
FREDERICK JOHN POYNTON
}

F. J. Poynton, son of the Rev. F. J. Poynton, rector of Kelston, Bath, was born in 1868 and died on October 29, 1943. He and his elder brother, A. B. Poynton, formerly Master of University College, Oxford, were both educated at Marlborough, in the welfare of which he remained keenly interested. He felt that he owed to one of his form masters there the impulse to take up his active medical career.

He started his medical studies at University College, Bristol, and won a scholarship at St. Mary's Hospital, London, in anatomy and physiology. Qualifying in 1893, he gained firstclass honours in the London M.B. the following year, took the M.D. in 1896, and was elected F.R.C.P. in 1903.

In 1900 Poynton became physician to out-patients at the Hospital for Sick Children and in 1903 assistant physician to University College Hospital. His work was done at these two hospitals with which he remained connected till the end of his life, though when he retired from the active staff in 1934, he went back to live near Bath, at Coombe Park.

Poynton will be mainly known for his work with Paine, trying to show that rheumatic fever with chorea was a specific infective disease and that it was caused by the Diplococcus rheumaticus. The latter part of this view was never widely confirmed and has not been accepted, and this has perhaps obscured a full appreciation of his other work bearing on acute rheumatism. When the time comes for a full understanding of the cause of acute rheumatism, it may be that his work will be found to have been along the right lines even if there were errors in the bacteriological technique.

His research work may be divided into these main stages. First in papers with Lees (Medico-Chir. Trans. , 81, 419, 1898) and Still (Trans. Path. Soc. London, 50, 324, 1899) and others, he dealt with the dilatation of the heart and the changes in the muscle during rheumatic fever, and with the histology of the rheumatic nodule, arguing from these that rheumatism was of infective origin. There are also statistics of some measurable features of rheumatism in children and good clinical observations-data which have helped to establish modern clinical views.

The second stage, in association with Paine, dealt more directly with the discovery of the Diplococcus rheumaticus. His first paper published in 1900 (Lancet, 1, 1352) represented some years intensive search for the infecting organism and results were not published until they had found it in the pericardium, in the heart muscle, in the joints, and in the rheumatic nodule, and until they had reproduced a good imitation of the disease in rabbits (an animal that has unfortunately proved itself a most unreliable guide for human pathology).

In the last group of his publications many of the papers are now of less interest as they were concerned with criticisms that had been made of the Diplococcus rheumaticus and with his rather too ardent defence of the work by himself and Paine. There are, however, others of more general clinical interest. One dealt with 52 of his cases of acute rheumatism in children under 5 years, 43 of them having heart disease: the features of rheumatic and pneumonic pericarditis were also contrasted (Quart. J. Med., (1908) 1, 225). Another on so-called scarlatinal rheumatism brought forward evidence that the disease is identical with ordinary rheumatic fever, having followed and complicated the original scarlet fever-a view which has now gained general acceptance (Quart. J. Med., (1909) 3, 15). Another discussed his view that malignant endocarditis might sometimes be rheumatic (Quart. J. Med., 5, 463, 1912) but he failed perhaps to prove that there was not a combination of a terminal infection on an old rheumatic valvu- 
litis. Yet this paper does show the importance of rheumatism as a cause of aortic valvular disease which has sometimes been overlooked or minimized.

In 1931, with Bernard Schlesinger, he published a book on Recent Advances in the Study of Rheumatism. He also wrote a small book on Heart Disease and Thoracic Aneurysm (1907) and with Paine republished many of his papers with the title Researches on Rheumatism (1913), a work dedicated to Lees, his friend and teacher. He ended this with a chapter on the prevention of acute rheumatism from which the following quotations are taken. He would, I think, have been pleased with the short review and the joint report on the Care of Rheumatic Children that follow this article.

" The importance of the prevention of an infection which is the great cause of organic heart affections in the young is one that cannot be over-rated; and we believe that definite results will be forthcoming because acute rheumatism is met with much more frequently among the poorer classes and is encouraged by those agencies, which may be summed up in the single word 'poverty.'

"In the great hospitals it is clear that we possess ample means for treating the acute disease and its complications and for advancing its study in many directions. Their value might well be strengthened in the future by the establishment of some special convalescent homes in carefully chosen sites for those recovering from early rheumatism including heart disease and chorea.

"We are convinced that the medical inspection of children in the State schools will in the near future provide us with valuable information upon the influence of school life on chronic rheumatic heart disease and on the relation of out-breaks of acute rheumatism to epidemics of sore throats.

"The education of parents and school teachers in the principal dangers of acute rheumatism might well be carried on by means of simple instructions and lectures. Among such instructions may be suggested the following for rheumatic children.

1. The importance of proper clothing.

2. The care of sore throats.

3. The necessity for attention to ' growing-pains.'

4. The importance of undue nervousness, clumsiness, and night-terrors, as warnings of chorea.

5. Parents should be warned that the early signs of heart disease are few, and that shortness of breath is more often complained of than pain.

6. Much emphasis should be laid upon need for patience when a child is recovering from heart disease.

7. Parents should be told that rheumatism is very liable to recur.

"We believe that more attention might be given to the condition of the tonsils and naso-pharynx in the rheumatic child, and also to the choice of an employment for those who have been damaged by the disease.

"The view that acute rheumatism is an infective disease raises again the important questions of climatic and local surroundings, sanitation, and conditions of housing. The possible relation that it may bear to other infective processes seems worthy of further inquiry.

"It is to prevention, then, that we look for some advance from this grievous state of affairs, and to this pressing need that we have ventured to publish this book."

Poynton never became deeply interested in modern cardiology and despite so much devoted and passionate work on the heart in rheumatism he was primarily a children's physician. It was here that he was at his best and his real understanding of the child as well as of its disease ensured his success, which was widely recognized as when he became President of the British Pædiatric Association in 1931.

Poynton was a good teacher and as one writer has said "His mischievous frankness of speech endeared him to students." He was also a good chairman of committees and was Senior Censor of the Royal College of Physicians in 1930.

He was a man with many interests and had been a fine cricketer who played for Somerset from 1891 to 1896; he also played hockey for Middlesex. He had a great love of music and a good tenor voice inherited from his parents. I am indebted to his friend Sir Henry Tidy for permission to quote the following appreciation, published in the British Medical Journal.

" Poynton was a character and sometimes appeared almost wishful to be an oddity. $\mathrm{He}$ was a countryman, and deliberately retained a countryman's characteristics with a certain scorn of personal appearance.

Short and stocky in build, he was enormously strong. He held the curious record of captaining a first-class county cricket eleven after attaining to the sober dignity of a Fellow of the College of Physicians. His outstanding cricketing feat was achieved in two hours at Hove 
when he and Sammy Woods scored 305 runs at top speed for Somerset against Sussex, and he loved to recall the episode. He played hockey for Middlesex and had some skill at real tennis. He had a fine tenor voice and sang for many years in the choir of St. James' Church.

Unfortunately he allowed his professional life to be clouded by what he considered to be the unsympathetic attitude of the profession towards his researches on rheumatic fever, though his resentment never extended to individuals. When speaking in public and at medical meetings he seemed to delight in supporting some illogical standpoint, and while he amused his audience he was not taken very seriously. But when he dealt with a sick child he had a knack of talking spontaneously as if they were equals, and every child felt at ease with him.

He was a delightful personal friend and a great companion on a holiday. He enjoyed every moment, and to the end he retained his power of boyish enjoyment, his sincerity and his honesty and his love of children."

MAURICE CAMPBELL. 